\title{
Discussion about the Art of Time and Space in "A Farewell to Arms"
}

\author{
Man Liu \\ School of Foreign Language \\ Changchun Institute of Technology \\ Changchun, China 130012
}

\begin{abstract}
In various novels of Hemingway, he built his own unique literary style. He extensively uses space-time consciousness in his novels and fully expresses the art of time and space which provide a deeper meaning for his novels. This article focuses on the art of time and space in Hemingway's novel "A Farewell to Arms", combined with in-depth analysis the application of art of time and space in the work in order to make more profound analysis for Hemingway's creation style.
\end{abstract}

Keywords-"A Farewell to Arms"; art of time and space; Hemingway

\section{INTRODUCTION}

"A Farewell to Arms" is a novel written by a famous American writer Hemingway. In this novel, Hemingway uses a broad range of time and space art method, he use the change of time and space to reflect the feelings of the characters and fiction content. The writer cleverly set time as the main line of the novel, after four seasons circle and to the tragic world move back and forth to highlight the ruthless and bloody war, protagonist Catherine manifested a firm spirit to overcome the tragic cycle is awe-inspiring. The application of space art has became a unique imagery in the novel, land space contains infinite pessimism has formed a strong contrast with the infinite hope contained by rivers, the main actor and actress male search for life in high mountains also symbolizes they acquired the height of life. Hemingway cleverly use art of time and space which gave the "A Farewell to Arms" more profound literary connotations.

\section{TIME ART OF "A FAREWELl TO ARMS"}

\section{A. Seasonal Cycle}

In "A Farewell to Arms", Hemingway fully apply the view of seasonal cycle to the specific story line. The seasonal circle highlight the time move in circles, the characters experience the four seasons repeat itself and without any change, reflecting the master's way of life is slim and his unchanged and repeated life experience is boring, through the cycle of seasons description build the work's nothingness meaning. The total time of the story in the book is 3 years, Hemingway also describes three times seasons change, and with the story line move forward, although time and season change as usual but the peaceful and stable images in seasons are less and bloody, chaos, war images become more and more, until the end the main actress dead in the winter of the third year. In the spring when main actor came across main actress, "look at the entire field, it is lush and road side trees grow new leaves while slight sea breeze blowing. I see the small town and the surrounded hills and castles, like a cup with its back peak slightly arched, there are little verdant grass on hillside"[2] This is a peaceful, beautiful and warm countryside spring, is a spring which nurtured the love seeds .Then, during the actor's recovering time in Milan, in the sunny, bright and warm summer, the actor and actress fall in love. However, in that autumn which "the leaves withered, bumpy road", birch leaves have fallen, withered grass all over the field. Dead trees laid on both sides of the road, the road filled with withered leaves", the war was defeated again and again, the actor returned to the front-line and happened to encounter a wide range of German counteroffensive, the Italian Army retreated in Kaposi Ruituo. On the way of evacuation since the actor has foreign accent so security forces mistaken him as German spy. He was arrested and then ran away, later he found the actress and they fled to Switzerland. But happy time was always so short, the actress had a difficult labour, when the bright spring was coming, the actress and the child were gone, the actor who lost his wife got back the hotel alone in the rain. From spring to summer, autumn until winter, with the protagonist's feelings warmingup, we seem to see hope, but as time goes by, it only brought us loneliness and death, like the cycle of seasons, even though people see different scenery in four seasons, but after all these changes is a reincarnation, all hope is futile.

\section{B. The Eternal Spirit to Overcome the Cycle}

This work "A Farewell to Arms" does not only highlight the topic of tragic life cycle, but reflects the eternal meaning and things in the process of constantly cycle. The Eternal that Hemingway proposed also included in the time cycle concept, the war was lost but the tragic figure did not completely surrender in the face of death, but continue to seek a new way to protest the death, Hemingway felt this spirit should be eternal [1]. The real hero does not pessimistically accept death, but exhausted body strength to break free, to go beyond. Although most of the Hemingway's works were ended by the death of the main actor, but he was always able to construct a eternal, a kind of spiritual transcendence. Although "A Farewell to Arms" was divided as the most pessimistic novel by many researchers, but in this work transcendency and break free also contains in it, which is the eternal spirit to overcome 
cycle. Although the actress has the same thought with Hemingway which death is the end of life, everything people do has no meaning, however, on the dying moment, she showed she hate disappointment because of her love and life is nothing but a deceptive scam, she had nothing to fear. Although the actress felt that life is meaningless, but she was deeply nostalgic for the life, because she understood the meaning of life which is "love," and finally, the actress readily accepted death, beyond the spirit.

\section{SPACE ART OF "A FAREWELl TO ARMS"}

\section{A. The Negative and Hopeless Brought by the Land}

Land and river images have the highest utilization rate in novel creation, Hemingway cleverly use these 2 spaces to build the characters' inner world [2]. The actor's unit stationed in the middle of the road and the river, a road linked the two things closely, Hemingway formed these three things a necessarily relationship, in the work the land is the only way for each life, the river was like human life and it has gone by every minute, road made a intersection point between life and being, however, choose a different road may lead to different life outcome. The land in "A Farewell to Arms" was the image of death, but only brought disappointment and negative to human. The actor's unit often traveling on a bumpy road, when the army rolled through always raising leaves and dirt on the road, but from the picture we can deeply feel the silence and desolation of the road, the blowing dust circle around in the air like crow lost direction, this made the soldiers felt deeply loneliness and disappointment. After being defeated by German troops, Italian troops decided to retreat to the place where army stationed, after heavy rain the road became very difficult to walk, vehicles always stuck in the ditch filled with water, it seemed to symbolized the war in trouble. The troops been attacked at front and back which made it closer to death, the soldiers have suffered enormous damage not only in body and hands but also in mind. This road in actor's eyes was endless even for a lifetime walk, the bloody war made road image more realistic, the entire army stuck into a negative mood, the road will be endless as long as the war continued.

\section{B. The Life and Passion Carried by the River}

The river in "A Farewell to Arms" symbolized a kind of forward power, the roaring river symbolized the dance of life which brought people a desire and enthusiasm for life. Although rivers and roads exist in actor's world at the same time, but the space images and perspective which author constructed was completely different, these two were compared subtly. At the beginning, the work described the stones in the river, stones had a golden dazzling light under sunshine, blue sky and white clouds reflected in the clear river, the river brought hope to the soldiers, they felt the passion and vitality of life which won the peace and rest in spiritual world. Rivers also created another road for the actor, during the arrest process by Italian military police, when the actor through the river bridge, he sought opportunities to escape, he knew that military police would seriously questioned and searched every person crossing the bridge, as long as there is a little doubt will be executed on the spot. He knew his accent will definitely expose himself so it was completely impossible to pass the river bridge, he immediately jumped into the rushing river while military police checking others, he flow along the river and it was the only way to get a chance to live. Here the work described the river carrying the actor's life and gave him a glimmer of hope, for the actor it was the start for his new life. Soldier's obligations and struggling in War era was thoroughly washed out in the river, he grabbed a piece of wood and swam ashore safely, the river made him understand the world more clearly, the war was nothing but to sacrifice the people and soldiers to gain the ruler's benefits. Therefore he decided to seek the outside world, his life was given a new meaning [3].

\section{The Height and Hope Presented by the Mountains}

In the works there was not much description about mountains, but it bred a deeper meaning, the river has given new life to the actor and led him to found the peak of life, which is the pursuit of a happy life. In the actor's hometown there was a high mountain called Abreu, villagers and the actor lived in this mountain surrounding hometown for generations, but he did not like this kind of life, he came to the city center and been invaded by modern civilization, alcohol and money filled in his lives. Abreu mountain and the city center formed a obvious contrast, the two regions reflected different cultural connotations, all affairs in modern cities are paralyzed and hypocritical, after the actor awaken, he began to like the quiet, easy life in hometown, the high mountains gave people the hope of life. After he met the actress, his values, attitudes changed obviously, parting and meeting of the war made them eager for a easy life, they desire the same height and intensity as the mountains. Therefore, they chose to settle in Montreux, Switzerland, and placed their home on the mountainside. This reflected the two protagonists pursuit the height of life, but in real life they can not reach such a high level, the actress dead in childbirth, left him die alone.

For Hemingway's novel "A Farewell to Arms", the study of art of time and space need to be further deepened. For art of time and space which deeply hide in Hemingway's works, we need a comprehensive, in-depth understanding of the subject of Hemingway, but also need to conduct multilateral research on the themes [4]. Hemingway was profoundly influenced Western Literature, Western writers actively absorbed the essence of Hemingway's work and profoundly influenced the creation of Western writers. Hemingway's presence was so strong, when we study Hemingway, it is difficult for us to feel him in other writers, because Hemingway was so unique, he was himself. Therefore, when we study Hemingway's art of time and space, his creative skills were also gave potential and invisible influence for the literary world.

\section{REFERENCES}

[1] Sun Zhili, Zhou Ye War and love interwoven in the narrative language --- feelings after retranslation of Hemingway's "A Farewell to Arms" [J] Journal of PLA Academy of Art, 2010,11 (02): 147-149.

[2] Long Xiaohua The symbolism in Hemingway's novel "A Farewell to Arms" [J] Journal of Qiqihar University (Philosophy and Social Sciences), Jan. 2009 (06): 324-326.

[3] Chen Caili, Chen Yushu Narrative tension and specious sincere loverRethinking of Catherine in "A Farewell to Arms" [J] Journal of Nanjing 
University of Aeronautics \& Astronautics (Social Sciences Edition) 2010,11 (01). : 3347349.

[4] Chen Yanping, Spiritual characteristics of the "Lost Generation" in "A Farewell to Arms"[J] Journal of Jilin Engineering and Technical Normal University 2009,30 (11): 211-215. 